\title{
The Analysis of Students' Critical Thinking Weakness in Senior High School on Physics Learning
}

\author{
Ahmad Fatih Musyarrof ${ }^{1}$, Sunyoto Eko Nugroho ${ }^{2}$, Masturi ${ }^{3}$ \\ 1,2,3 Physics Education, Graduate School, Universitas Negeri Semarang, Indonesia \\ ${ }^{1}$ Corresponding author : ahmadfatihmusyarrof@gmail.com
}

\begin{abstract}
The $21^{\text {st }}$ century skills to be the attention of education especially in Indonesia nowadays. One of the $21^{\text {st }}$ century skills that student must possessed is the critical thinking ability. In physics learning, students should be able to think critically in analyzing a problem. Unfortunately, the attention to the critical thinking skills has not been much emphasized in school learning. This research aimed to analyze the weaknesses of students in thinking, especially in critical thinking on the learning of physics. The subject of this research are 33 students of SMA Negeri 1 Temanggung in grade 11. There are four critical thinking indicators that used as reference: clarification, assessment, inference and strategies. Found that students tend to be weak in analyzing problems, in evaluating and making decisions.
\end{abstract}

Key Words: $21^{\text {st }}$ century skill, critical thinking, physics learning

\section{Introduction}

The world change in the $21^{\text {st }}$ century requires a country to be able to compete globally. It can not be separated from the role of human resources. One important aspect that has a major impact on the quality of human resources is education. Education in the 21st Century has been influenced by technology and globalization (Drake \& Reid, 2018).

Nowadays, the development of aspects of education competency refers to the 21st century skills aspect. The Partnership for 21st Century Skills presented the $4 \mathrm{Cs}$ of critical thinking and problem solving, communication, collaboration, and creativity plus innovation because they are essentials for success in college, career, and life outside educational institutions (Kivunja, 2015). Indonesia, the $4 \mathrm{C}$ aspect of competence has become concern by the government to be applied in to the education system.

As an object of education, students are required to be able to adapt to the development of world education. We need to prepare students not only for employment in a sustainable economy, but also with the skills and values that will allow them to live sustainable lifestyles on this world (Bell,2016) . To thrive in a rapidly evolving, students must not only possess strong skills in areas such as language arts, mathematics and science, but they must also be adept at skills such as critical thinking, problem-solving, persistence, collaboration and curiosity (World Economic Forum, 2015).

In the study of physics, aspects of critical thinking become important to get attention.
Critical thinking is described as a metacognitive process, consisting of a number of sub-skills that increases the chances of producing a logical conclusion to an argument or solution to a problem (Dwyer et al., 2014). The skill of critical thinking allows to reflect criticaly on learning processes and learning experiences (Tikhomirov et al., 2015). Students are required to be critical in thinking of solving physics problems.

The goal of any high school is to ensure that its students have the knowledge and skills they need to be successful (Sullivan \& Dallas, 2010). Teachers play a significant role in helping students develop 21 st century skills by applying methods that increase students' abilities (Alismail \& McGuire 2015). Unfortunately, attention to the improvement of critical thinking skills is still not seen in the teaching and learning activities in the classroom.

For improving the ability to think critically, students' weaknesses in critical thinking need to be observed. By paying attention to the weaknesses in critical thinking, teacher as an educator will be able to predict the best learning strategy to gain students' thinking ability.

\section{Method}

This paper based on a study that conducted to describe students' weaknesses in critical thinking in physics learning. In this case, the study was conducted on parabolic motion subject. The question related to parabolic motion given to 33 students of grade 11 SMA Negeri 1 Temanggung. Students have been previously equipped with knowledge about parabolic 
motion in the classroom learning. The questions related to parabolic problems that are based on phenomena that can occur in everyday life. Students are required to determine the distance between the release point and fall point of a dropped bomb (at x-axis) by a flying plane at a speed of $100 \mathrm{~m} / \mathrm{s}$ and at a height of 500 meters with a gravity acceleration of $10 \mathrm{~m} / \mathrm{s} 2$, ignoring the friction between the bomb and the air.

The critical thinking indicators that used are clarification, assessment, inference and strategies. Clarification consists of analyzing the problem and identifying an important part of a problem. Assessment consists of selecting relevant information and assessing it for logical reasons. Inference consists of performing the completion algorithm and giving a conclusion. While the strategy consists of re-examining answers and trying to find other solutions idea. From the results that given by students, students' weaknesses in critical thinking will be analyzed and discussed descriptively.

\section{Result and Discussion}

Students have previously gained knowledge of the concept of parabolic motion through teaching and learning activities in the classroom. The results of the students answers reflect of what they understand and appear in their mind. From the analysis, it was found that only 2 students who correctly answered the question, 28 students answered wrong and 3 students did not give any answer. From the answers, we found some weaknesses of students in critical thinking. The weakness of critical thinking directly can be seen by seeing how the student gives visualization of bomb movement.

Student's weakness in critical thinking can be seen from how the student describes the trajectory of falling bombs. Figure 1 shows that the students ilustrated the bomb-motion trajectory curve toward the direction of the plane's speed. This shows that students are less of critical in thinking. Ignoring the bomb friction with the air, the direction of the plane's should affects the direction of the dropping bomb. The direction of the bomb trajectory curve should be in the same direction as the plane's speed.

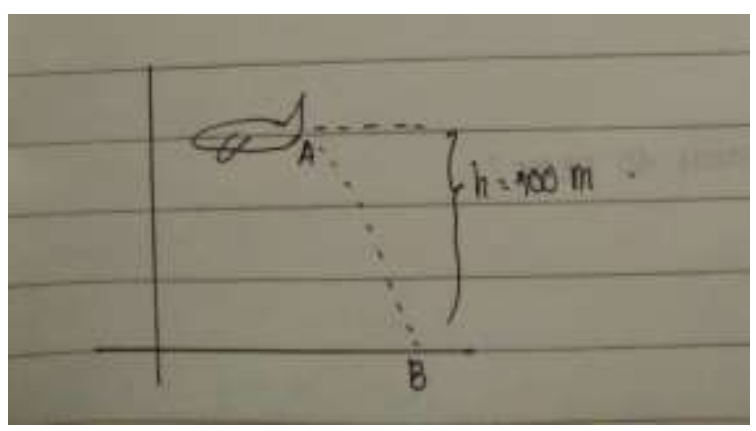

Figure 1. One of students answer that less of critical in making visualization.

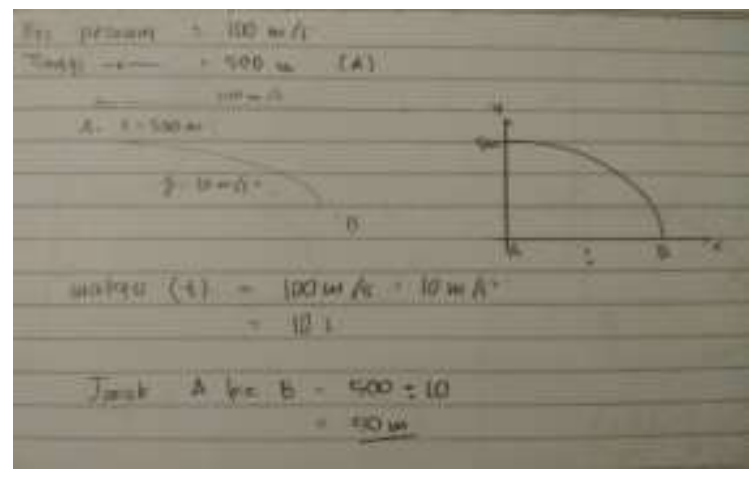

Figure 2. One of students answer who do not understanding the concept.

Lack of data and weak in logic may cause the weakness in analyzing problems. It also have an impact on the process of identifying the parts of the problem. Students become unfocused in digging and developing the information they have and do not understand what is the main purpose of the given problem.

Student's knowledge of concepts is needed in solving physics problems. Incomplete concepts have an impact on the the overall solving process and the answers given. In evaluating a problem, the whole concept becomes a tool for being able to parse appropriate and relevant information and assess the problem for logical reasons. Figure 2 shows the results of students' answers that understand the direction of the problem but the concept of parabolic motion is not well understood. Seen from the answers given, the student's knowledge is interrupted at some point and unable to find or explore other knowledge possessed. Students are not able to link well between one concept with another supportive concept to solve the problem. 


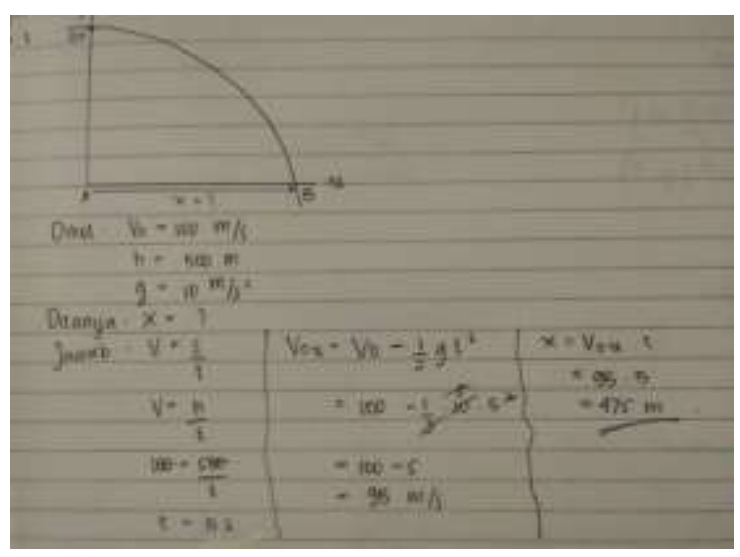

Figure 3. The results of student answers who do not critical in making decisions.

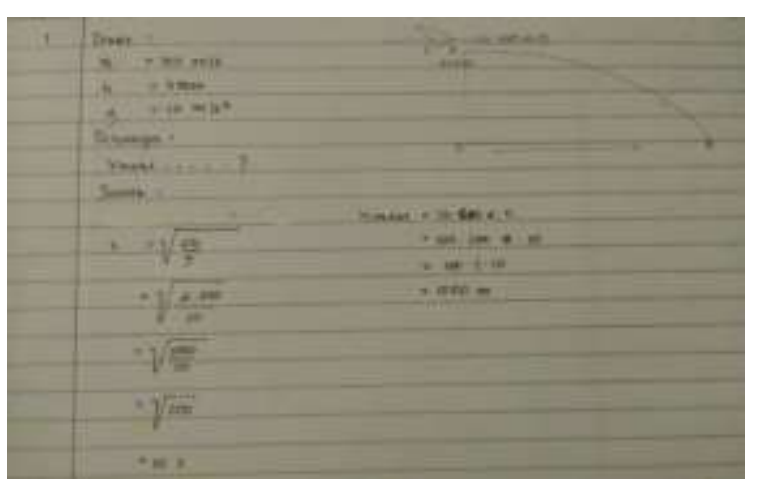

Figure 4. The results of student answers who answered correctly

Figure 3 shows the results of students' answers who understand the purpose of the given problem and understand the concept of parabolic motion but not critical in making decisions. The whole parabolic motion concept becomes the determining factor in the accuracy of decision making. Data collected through the problem evaluation process can be fully explored by the students. The student understands what is needed to solve the problem but not correct in determining the equation that used. Improper decisions have an impact on the overall process of completion of the algorithm. In this case, the students basic concepts of physics must be strengthened as it relates to how the students' imagination in visualizing, developing ideas, gathering information and making decisions.

Figure 4 show the answer of the students who are able to think critically. From the bomb trajectory visualization, students understand that the direction of the plane's has an effect on the direction of the bomb curve. The whole concept has made students able to identify problems well. Students understand the given problem and able to gather the important data as a part of the problem, digging information, expanding and assessing information logically. However, there are some weaknesses in terms of the decisionmaking process. Students are hampered by shortcut equation so the thinking processes can not be developed properly. Nevertheless, the answers provided indicate that students understand and are critical in thinking and making decisions so that the completion of the algorithm produces the correct answer.

\section{Conclusion}

In general, students of grade 11 SMA Negeri 1 Temanggung are weak in critical thinking. Student's weakness in critical thinking is in aspects of analyzing problems, evaluating and making decisions. The ability of students to logic in providing visualization of motion is low. Not understanding the concept is the main cause of weak students in developing the information they have. The lack of information results in the inability of students to relate between one concept with another concept that corresponds to the given problem. Students physics concepts and thinking flow in solving problems need to be considered more deeply so that students can be critical in thinking.

\section{Reference}

Alismail, H. A. and McGuire, P. 2015. $21^{\text {st }}$ Century Standards and Curriculum: Current Research and Preactice. Journal of Education and Practice, 6 6, 150-154. https://eric.ed.gov/?id=EJ1083656

Dwyer, C. P., Hogan, M. J. and Stewart, I. 2014 An Integrated Critical Thnking Framework for The $21^{\text {st }}$ Century. Thinking Skills and Creativity, 12, 4352.

Drake, S. M. and Reid, J. L. 2018. Integrated Curriculum as an Effective Way to Teach 21st Century Capabilities. Asia Pasific Journal of Educational Research, 1 1, 31-50.

Kivunja, C. 2015. Exploring the Pedagogical Meaning and Implications of the 4Cs " Super Skills " for the 21 st Century through Bruner's 5E Lenses of Knowledge Construction to Improve Pedagogies of the New Learning Paradigm. Creative Education, 62 , 
224-239. https://doi.org/ $10.4236 /$ ce. 2015.62021

Bell, D. V. J. 2016. Twenty-first Century Education: Transformative Education for Sustainability and Responsible Citizenship. Journal of Teacher Education for Sustainability, 18 1, 4856.

World Economic Forum, New Vision for Education Unlocking the Potential of Technology. 2015.

http://www3.weforum.org/docs/WEFU

SA_NewVisionforEducation_Report2 015.pdf (Retrived $1^{\text {st }}$ July 2018).
Tikhomirov V., Dneprovskaya N. and Yankovskaya E. 2015. Three Dimensions of Smart Education. In: L. Uskov V., Howlett R. and Jain L. (eds) Smart Education and Smart eLearning. Smart Innovation, Systems and Technologies, 41, 47-56.

O'Sullivan, M. K. and Dallas, K. B. 2010. A Collaborative Approach to Implementing $21^{\text {st }}$ Century Skills in a High School Senior Reseach Class. Education Libraries, 33 1, 3-9. 